\title{
Fish Pass Functionality in Relation to the Dynamics of Hydrological Conditions in the Upper Course of the River Iskar (Case Study)
}

\author{
Silviya Petkova ${ }^{1 *}$, Emil Kanev², Ina Dimitrova' ${ }^{1}$ Dimitar Kisliakov ${ }^{1}$ Eliza Uzunova ${ }^{2}$ \\ 1 Department of Hydraulic, Irrigation and Drainage Engineering, University of Architecture, Civil engineering \\ and Geodesy, $1 \mathrm{Hr}$. Smirnenski Blvd., 1046 Sofia, Bulgaria \\ 2 Department of General and Applied Hydrobiology, Faculty of Biology, Sofia University, 8 Dr. Tsankov Blvd., \\ 1046 Sofia, Bulgaria \\ * Corresponding author’s e-mail: s.sasheva@gmail.com
}

\begin{abstract}
The investigated fish pass is a part of a low-head hydrostatic pressure machine (HPM) located on an existing weir in the upper Iskar River. Monitoring of the hydraulic features of the fish pass was performed under different hydraulic conditions. Diversity and abundance of the local fish fauna was investigated with the aim to verify target fish species. A major limiting factor for using of the fish pass during flood periods was high water velocity (both inside the fish pass and at the fish pass downstream entrance), while during the low water discharge periods it was the insufficient water depth in some pools and the significant differences between the water levels in adjacent pools. The difference between the water levels at the entrance and exit of the fish pass reduces the chances for access of small-sized fish species. Some measures for improving fish pass functionality were developed. Several re-construction solutions were proposed in an attempt to help solving the identified problems.
\end{abstract}

Keywords: fish pass, hydraulic conditions, Iskar River, Bulgaria

\section{INTRODUCTION}

Physical obstructions in rivers are becoming increasingly recognized as a major factor negatively influencing the migration, diversity, population structure, spawning success and recruitment of freshwater fishes [Nilsson et al. 2005, Hall et al. 2005]. Even very low head weirs can constitute impassable barriers to movements and dispersal of small, potamodromus fish species [Ovidio et al. 2002, Poulet 2007, Amaral et al. 2007].

The longitudinal connectivity of the upper course of the longest Bulgarian river - Iskar (Danube river basin) is severely disturbed by the existence of over 110 fragmentation structures of anthropogenic origin [Kanev et al. 2016]. A weir located at the area called „Mechkata” is the first obstacle for fish migration to the upper courses of Iskar and Palakaria rivers. At this point, restoration could increase the available habitat for the fish dispersal within $2 \mathrm{~km}$ from the Iskar
River and another $20 \mathrm{~km}$ from the Palakaria River which is a part of the European ecological network Natura 2000. With limited financial resources for construction of new fish passes, solutions should be sought through co-building small eco-friendly hydro power plant (HPP) equipped with fish pass facilities [Therrien et al. 2000]. Such eco-friendly HPP with a so-called hydrostatic pressure machine (HPM) for very low head (i.e. $0.50-2.50 \mathrm{~m}$ ) was developed and introduced during the research project HYLOW (www.hylow.eu) of the $7^{\text {th }}$ Framework Programme of the European Commission. An extensive study on the conditions for fish passage through the wheel of the HPM recorded a low level of fish injuries [Uzunova et al. 2014]. Along with the HPM, an experimental fish pass was built as a tool for restoration of the river connectivity [Vowles et al. 2014]. A major challenge for the fish pass construction in the upper reaches of inland rivers in Bulgaria is the large amplitude in annual water 
discharge. This requires adaptation of fish passage facilities to seasonal hydraulic changes, as well as specific species composition.

This study aims at evaluating the hydraulic features of the fish pass under the different hydraulic conditions and developing the suggestions for improving the functionality of the facility. The specific tasks were formulated as follows: 1) Assessment of the fish pass hydraulic parameters under different water flow conditions; 2) Assessment of the fish species diversity, fish abundance and biomass downstream and upstream of the weir and identification of target species; 3) Formulation of measures to improve the efficiency of the fish pass in relation to the target species (if necessary).

\section{MATERIAL AND METHODS}

\section{Study area}

The small hydroelectric power plant equipped with the hydrostatic pressure machine (HPM) and the experimental fish pass were constructed at the existing weir in the upper section of the Iskar River (location "Mechkata"), Figure 1. The geographic coordinates of the site are N 42 $25^{\prime} 50.2^{\prime \prime}$ and E $23^{\circ} 31^{\prime} 53.9^{\prime \prime}$. The existing weir is a massive concrete structure and it was built in the mid1990 s as a triangle-shaped measuring facility. The upper Iskar River flow regime is characterized by the low water period from August to October, and high water period from April to July, see Figure 2.

\section{Fish pass assessment}

The existing fish pass is a technical, pool-weir type, see Figures 3 and 4. The fish pass was installed parallel to the main river flow on the left side of the weir and to the right of the HPM canal. The fish pass was made of concrete and gabions. The bottom surface was covered with built-in cement gravels with size up to $10 \mathrm{~cm}$. The pass is $22 \mathrm{~m}$ long, with internal widths varying from $0.92 \mathrm{~m}$ to $1.44 \mathrm{~m}$. The fish pass consists of 8 separate pools divided by $0.20 \mathrm{~m}$ thick and $0.20 \mathrm{~m}$ high separation walls. Each wall has an orifice with the width of $0.80 \mathrm{~m}$ and height of $0.18 \mathrm{~m}$ (from the bottom). The average slope of the fish pass is $6 \%\left(3.8^{\circ}\right)$. The measurements of the hydraulic characteristics were performed in May, August, October and December 2017.

A set of hydro-morphological and physical parameters was used to assess the passability of the fish pass, according to the methodology described in SNIFFER [11]. The main measured parameters were as follows: the water depth in each pool ( $\min$ and max), in front of the entrance and after the exit; water velocity (bottom and $0.6 \times$ height of the water column) in each pool, in front of the entrance and beyond the exit; visual survey for lips, standing waves, turbulence, resting areas for fish, debris. The water velocity was measured by means of a highly accurate water flow probe (model FP101, Global Water Instrumentation, Inc., USA). In some periods of high water flow, the fish pass was inaccessible and measurements could not be made.

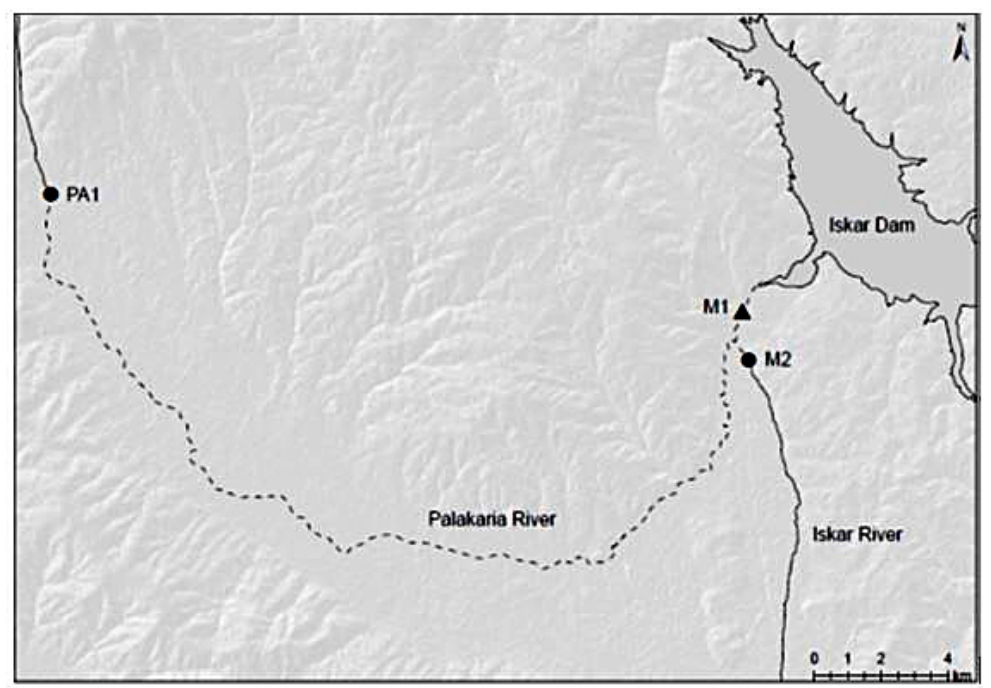

Figure 1. Map of the study area with designated location of the existing HPM facility and fish pass (M1). The dotted line indicates the potentially released way of migrating fish from Iskar Reservoir to the upper stretches of Iskar and Palakaria rivers. M2 and PA1 - fragmentations impassible for fish 


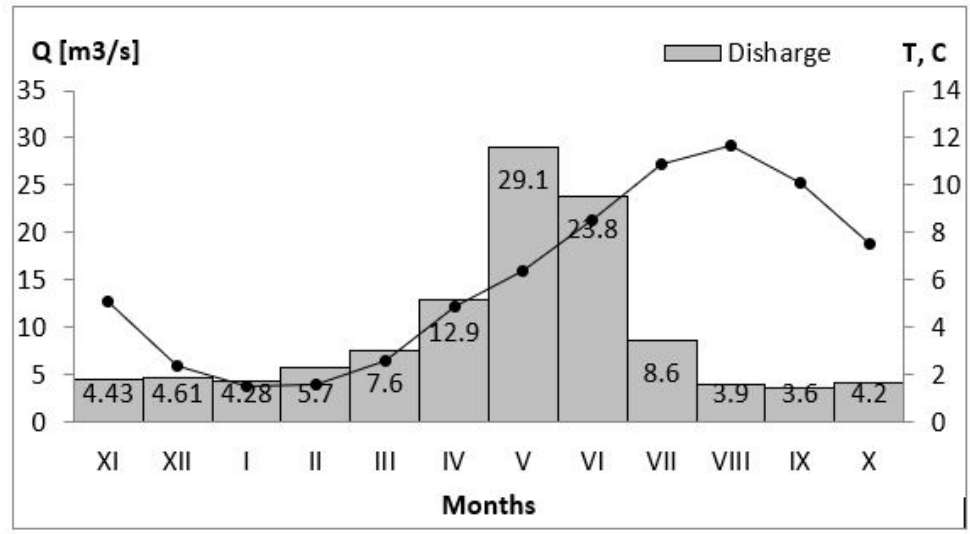

Figure 2. Monthly distribution of runoff of the Iskar River near „Mechkata” [according to Hristova 2012]

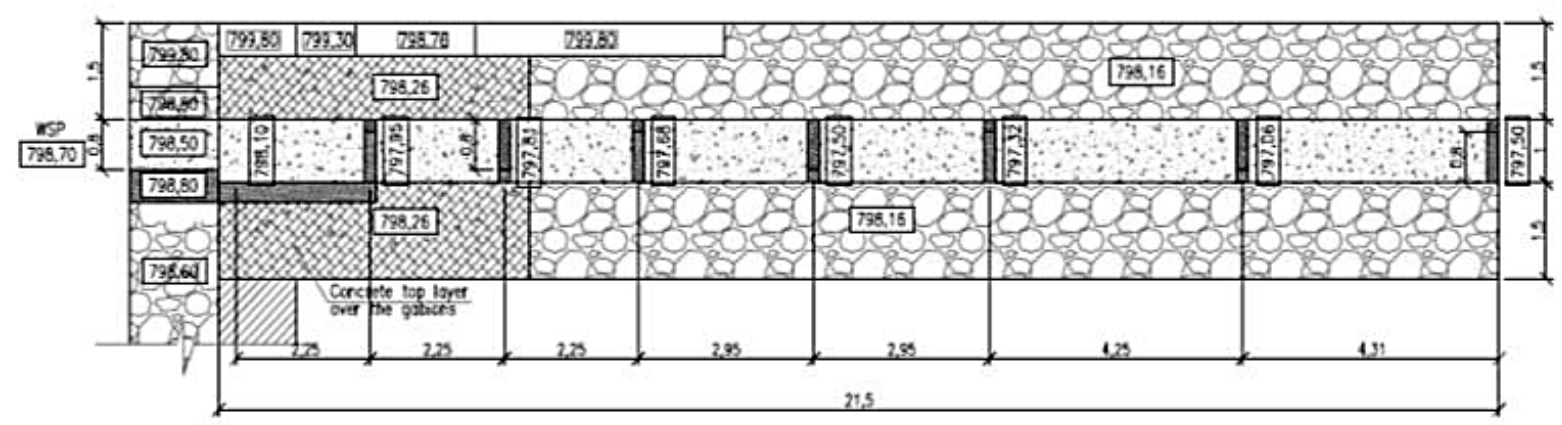

Figure 3. Layout of the existing fish pass located on a weir in the upper course of the Iskar River

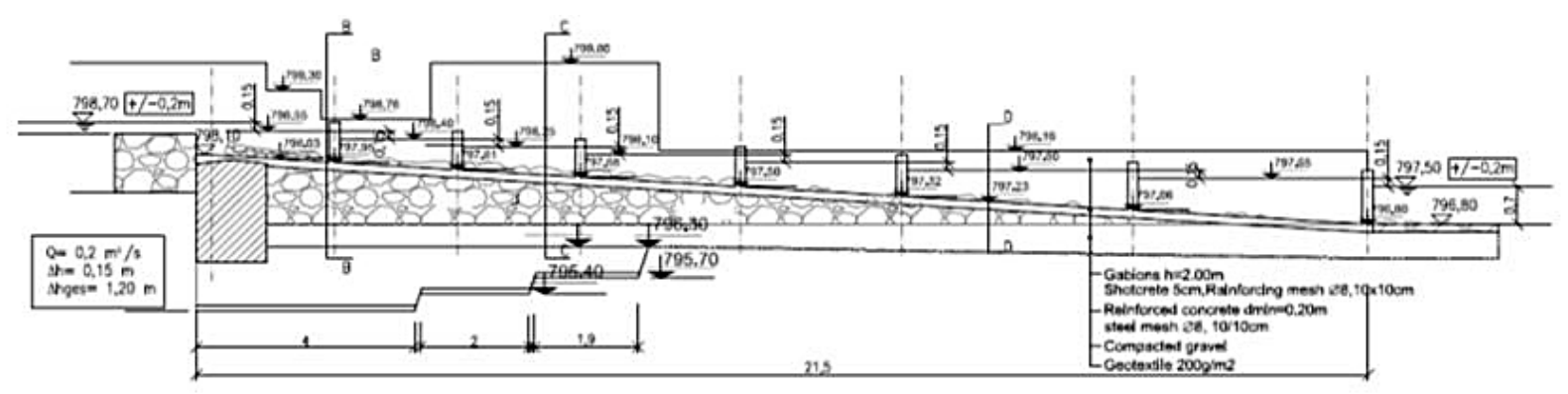

Figure 4. Longitudinal section over the fish pass located on a weir in the upper course of the Iskar River

\section{Fish collecting}

Fish was collected during the low water level period (August 2017) using electrofishing devices on 4 sites located upstream and downstream of the weir. The taxonomic status of the species was determined in situ [Kottelat et al. 2007]. The conservation status was determined according to the Red Book of Bulgaria, the Biodiversity Act (2002), EU legislation and international conventions. Fish abundance and biomass were calculated as number of fish /grams per $100 \mathrm{~m}^{2}$. The criteria for determining the target fish species were their conservation status and migratory behavior.

\section{RESULTS AND DISCUSSIONS}

A total of 19 fish species belonging to 6 families (Cyprinidae, Salmonidae, Percidae, Centrarhidae, Cobitidae, Nemacheilidae) were found in the investigated sites. All 19 species were found downstream, and 13 of them upstream the weir. Two fish species inhabiting this river section before constructing the weir were not found and could be considered as extinct - bullhead (Cottus gobio) and nase (Chondrostoma nasus) [Kanev et al. 2015, Uzunova et al. 2012a]. Significant differences in the abundance of the dominant species downstream and upstream of the weir were 
recorded, see Figure 5. Total fish abundance was higher in the upstream area (4.4 vs 3.4 ind. per $100 \mathrm{~m}^{2}$ ). The abundance of the Romanian barbel (Barbus petenyi) was higher in the downstream area compared to the upstream. The opposite trends were observed for other dominant species - common minnow (Phoxinus phoxinus), chub (Squalius cephalus) and Balkan spined loach (Sabanejewia balcanica). The highest species abundance (28.75 ind. per $100 \mathrm{~m}^{2}$ ) was recorded at the site situated upstream for common minnow (Phoxinus phoxinus). The predominance of limnophilic species observed upstream the barrage was a result of a "damming effect" and the accompanying changes to the habitat. The trend established after the construction of the fish pass in 2011. The increasing total fish abundance in the area above the barrier is still preserved [Uzunova et al. 2012a].

The selected target species for which the fish pass facility was tested were those listed in Annex II of the EC Council Directive 92/43: stone gudgeon (Romanogobio uranoscopus), sand gudgeon (Romanogobio kessleri), bitterling
(Rhodeus amarus), Romanian barbel (Barbus petenyi), Spined loach (Cobitis taenia) and Balkan spined loach (Sabanejewia balcanica) and also brown trout (Salmo trutta) as a short distance migratory fish [Uzunova et al. 2012b]. More significant reproductive migration is carried out mainly by the species Salmo trutta and Barbus petenyi. With the exception of brown trout and chub, all species found in area are small-sized with limited swimming and jumping capacities.

The passability of the fish pass ranged between 0 and 0.6 under different hydrological conditions according to the SNIFER classification.

The water velocity $\left(>2.0 \mathrm{~ms}^{-1}\right)$, both inside the fish pass and at the fish pass downstream entrance, was a major limiting factor for the entry and movement of fish through the fish pass during high water periods. High turbulence and standing waves downstream of the fish pass were observed under the flood conditions. The water level difference at the entrance of the fish pass was $0.25 \mathrm{~m}$, which is higher than the overcoming ability of the most fish species inhabiting the upper river's riches.

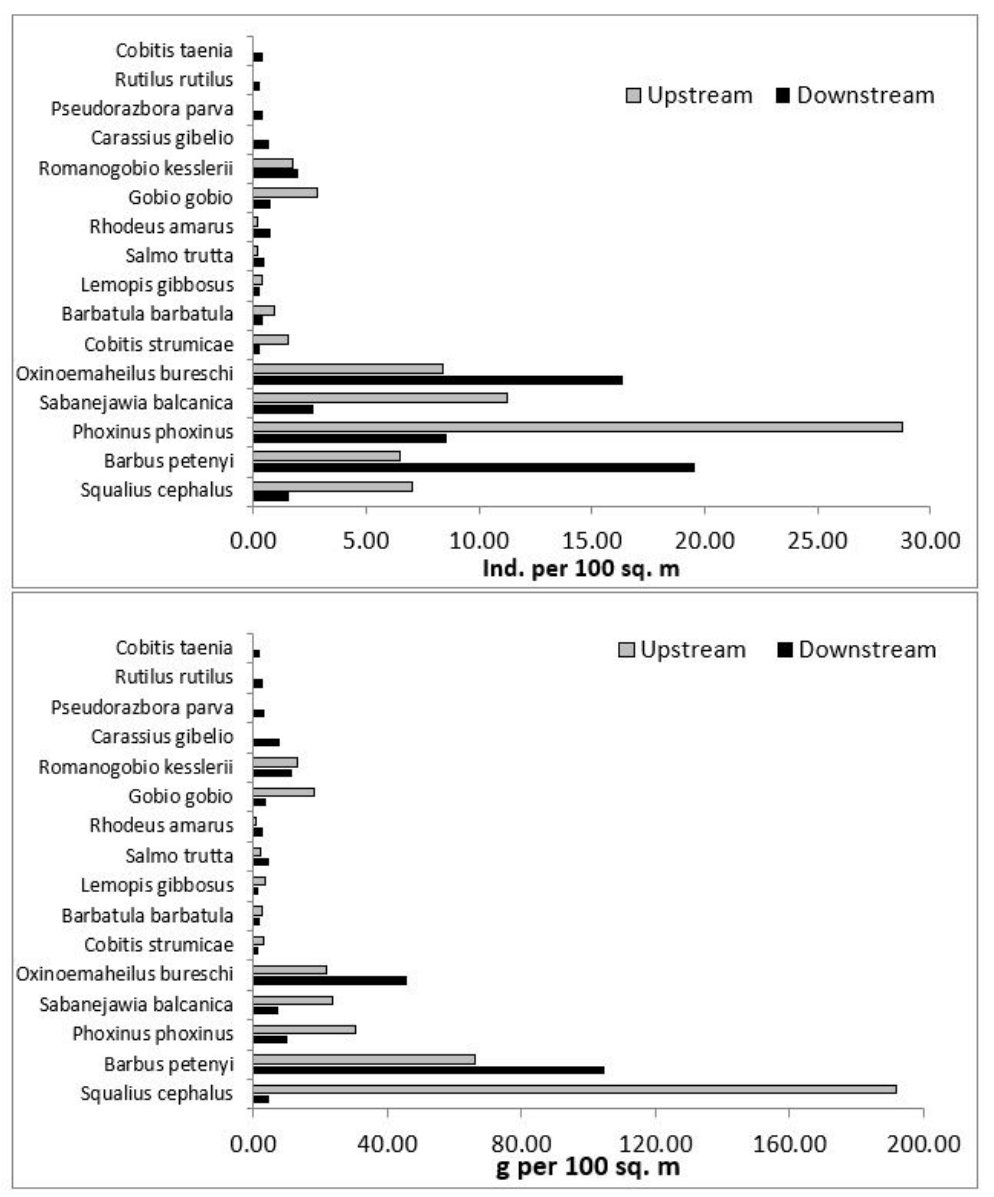

Figure 5. Abundance (ind. per $100 \mathrm{~m}^{2}$ ) and biomass (grams per $100 \mathrm{~m}^{2}$ ) of the different fish species upstream and downstream of the weir in location "Mechkata" 
The insufficient water depth in some pools and significant differences between water levels in adjacent pools constituted major limiting factors for fish migration during the low water periods. During low water periods, the speed of the water at the fish pass outlet was lower $\left(<0.05 \mathrm{~ms}^{-1}\right)$ than the required attractive flow $\left(<0.2 \mathrm{~ms}^{-1}\right)$. The operation of HPM under low water conditions led to higher water velocity in the power channel outlet comparing to the fish pass. The water velocity at the outlet was over $2.00 \mathrm{~ms}^{-1}$, which distracted the fish and interrupted their accessibility to the downstream entrance of the fish pass. The low height of the water column on the separation slabs $(\sim 0.02 \mathrm{~m})$; significant height of the last step before leaving the fish passage $(0.32 \mathrm{~m})$, sediment deposition between the upstream fish pass entrance and the dammed area additionally hamper the fish passability and reduce the functionality of the facility.

\section{Recommendations and fish pass improvements}

The pool-weir type fish passes are not very suitable for non-salmonid and small-sized fishes
[BMLFUW 2012]. The local fish of the Iskar river fauna was dominated by fish species with low swimming and jumping abilities. The largest fish species that are expected to inhabit the area are chub, nase and brown trout, with the average maximum length of $0.25-0.35 \mathrm{~m}$. Small species, like most of the identified target species, cannot handle high velocities and turbulences. Therefore, the level differences in adjacent pools should not exceed $7.00-13.00 \mathrm{~cm}$, and energy dissipation should be below $100 \mathrm{Wm}^{-3}$. The slope of the fish pass should not exceed 4\%. Provision of natural substrate at the bottom of the fish pass is needed as well, if necessary, embedded into concrete to avoid flushing it out. The downstream entrance of the fish pass has to be under the water surface and the bottom to merge with the natural bottom of the river.

As particular recommendations for a solution to the identified problems, different suggestions for improvements of the fish pass performance and the river connectivity were developed as particular recommendations to solve the identified problems. Some of them involve constructing an additional pool and a small ramp covered with

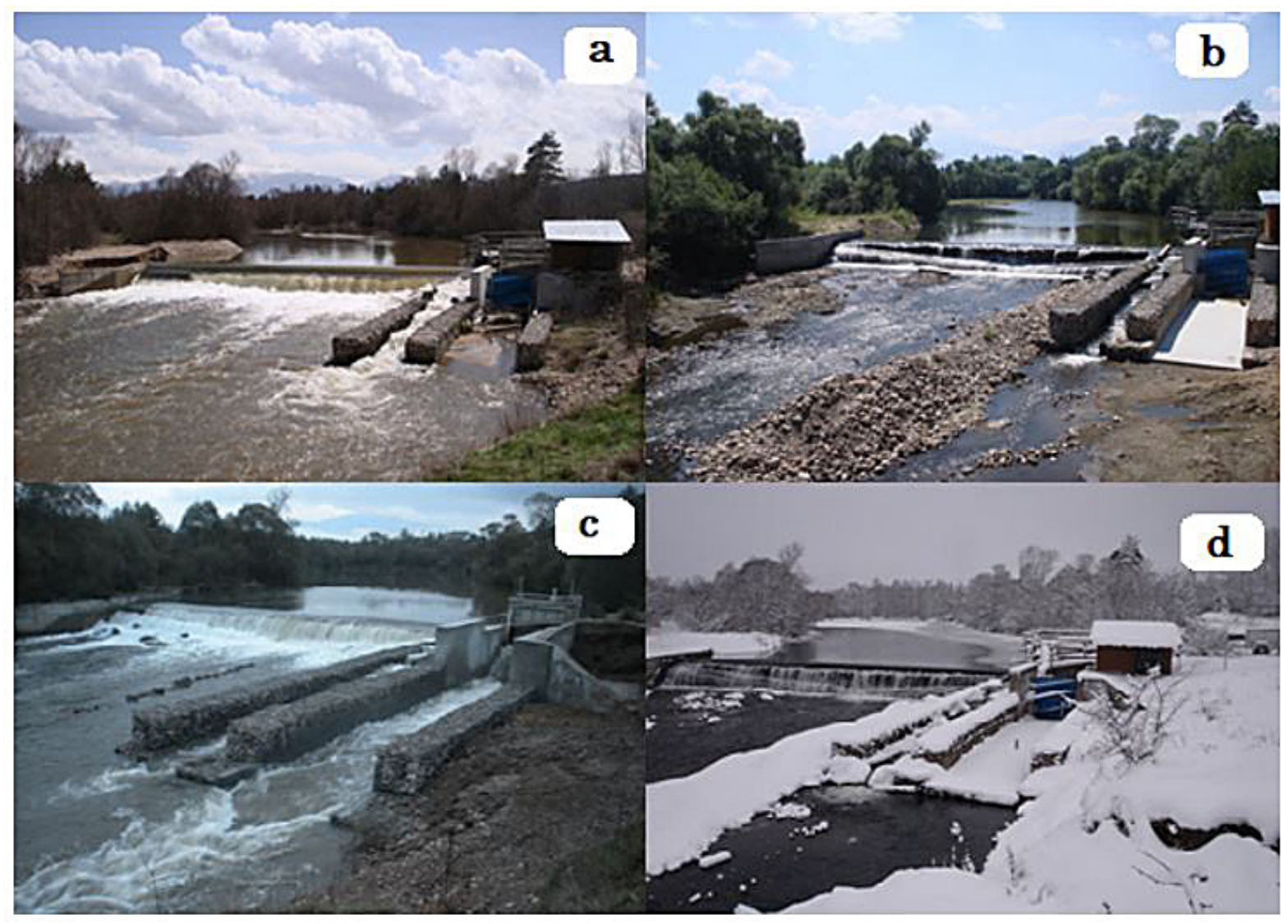

Figure 6. Different hydraulic conditions of the river Iskar at location Mechkata: April (a), June (b), September (c), December (d) 


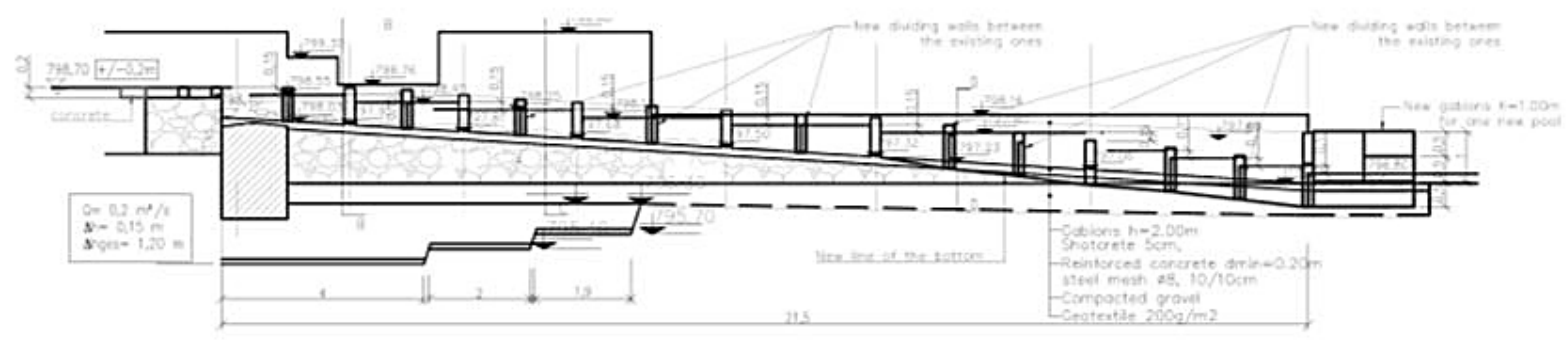

Figure 7. Fish pass reconstruction - longitudinal section

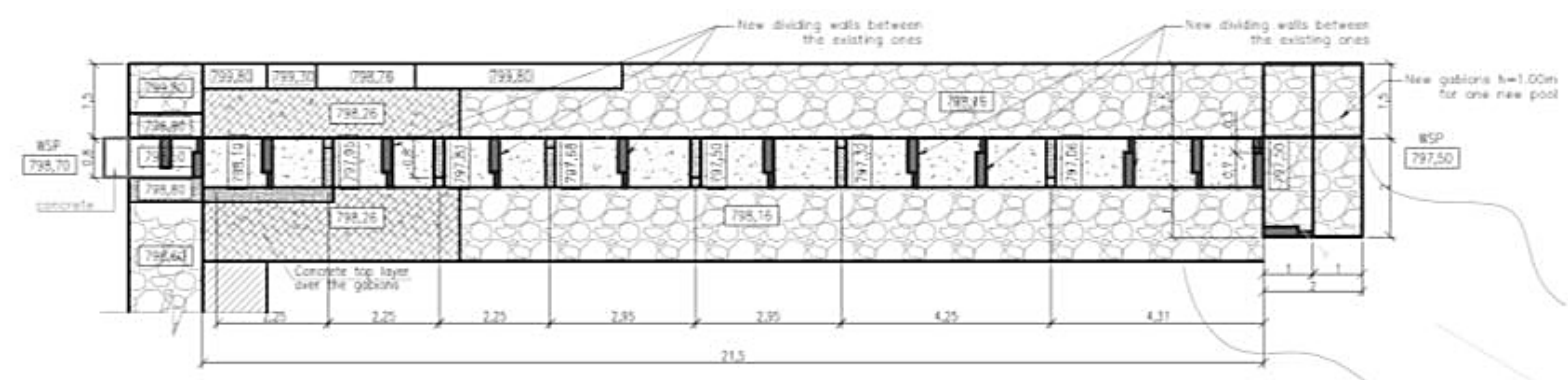

Figure 8. Fish pass reconstruction - layout

large stones in front of the first step (entrance). Two additional pools have to be formed before the exit to reduce the difference in water levels in the current last step, see Figures 7 and 8.

The following objectives have to be met to achieve the recommended improvements:

1) The entrance to the fish pass must be more easily discoverable and accessible for smaller fish species;

2) The height of the last step of the fish passes, immediately before the upstream exit, must be reduced to allow fish to pass into upstream area;

3) In some pools of the fish pass, the resting zones have to be created;

4) In the entire channel, the flow turbulence has to be minimized, to avoid fish disorientation and exhaustion.

\section{CONCLUSIONS}

Reconstruction of existing weirs with environmental-friendly HPP equipped with fish pass facilities is a possible approach to the restoration of the river continuity and utilization of novel hydraulic solutions for energy production. On the basis of the fish diversity and abundance in upstream and downstream area, it can be concluded that the operation of the fish pass over several years achieves longitudinal river connectivity to some extent but some hydraulic features of the fish pass need more complete adaptation to the swimming characteristics of the local fish fauna.

The results of the particular study confirm both the generally proper concept of the original design and the necessity of proper monitoring and operation of the fish pass under real conditions.

\section{Acknowledgements}

The presented study was conducted under the research project "Entwicklung eines ökologisch verträglichen, modularen Systems zur Nutzung kleiner Wasserkräfte mit sehr niedrigen Fallhöhen" and would not have been possible without the financial support of the German Federal Ministry of Environment and Reactor Safety (Bundesministerium für Umwelt und Reaktorsicherheit) and subsequently by the Federal Ministry of Economics and Energy (Bundesministerium für Wirtschaft und Energie).

\section{REFERENCES}

1. Amaral S. D., P. Branco, A. Teixeira da Silva, C. Katopodis, T.Viseu, M. T. Ferreira, A. N. Pinheiro \& J. M. Santos (2016), Upstream passage of potamodromous cyprinids over small weirs: the influence of key-hydraulic parameters, Journal of Ecohydraulics, 1:1-2, 79-89 
2. BMLFUW Guidance on the Construction of Fish Passes, (2012) Federal Ministry of Agriculture, Forestry, Environment and Water Management, Vienna, Austria

3. Hall C.J., Jordaan A, Frisk M.G. (2012), Centuries of anadromous forage fish loss: consequences for ecosystem connectivity and productivity, BioScience 62(8), 723-731

4. Hristova N. (2012), Rivers of Bulgaria, Tip - Top Press, (In Bulgarian)

5. Kanev E., M. Mitankina, K. Ignatov and E. Uzunova (2016), Longitudinal connectivity for fish migration in upper reaches of the Iskar River and prioritization of the restoration measures, Procc. of $41^{\text {st }}$ International Association for Danube Research (IAD) Conference

6. Kanev E., E. Uzunova (2015), Effects of habitat fragmentation on current distribution of the genus Cottus (Cottidae) in Bulgaria, International Conference on river connectivity: Best practices and innovations, Holland

7. Kottelat, M., J. Freyhof (2007), Handbook of European freshwater fishes, IUCN SSC, Cornol, CH: Publications Kottelat

8. Nilsson C, Reidy C.A., Dynesius M, Revenga C. (2005), Fragmentation and flow regulation of the world's large river systems, Science 308, 405-408

9. Ovidio M., Philippart J.C. (2002), The impact of small physical obstacles on upstream movements of six species of fish - synthesis of a 5-year telemetry study in the River Meuse basin), Hydrobiologia, 55-69

10. Poulet N. (2007), Impact of weirs on fish commu- nities in a piedmont stream, River Research and Applications, 23, 1038-1047

11. SNIFFER, Water Framework Directive (2010), Coarse resolution rapid-assessment methodology to assess obstacles to fish migration: field manual, level A assessme, Edinburgh: Scotland and Northern Ireland Forum for Environmental Research

12. Therrien, J, and G. Bourgeois (2000), Fish Passage at Small Hydro Sites, Report by Genivar Consulting Group for CANMET Energy Technology Centre, Kanada

13. Uzunova, E., I. Milanova, A. Futekova, \& L. Rashkova \& E. Tasheva (2012a), Fish Diversity and Community Structure in a Highly Fragmented Section of the Upper Iskar River, Bulgaria), In: Proceedings of the International Conference Ecology - Interdisciplinary Science and Practice, Bulgaria, Part 2, 215 - 225.

14. Uzunova, E., A. Futekova, I. Milanova \& L. Rashkova (2012b), Effect of River Fragmentation on the Abundance and Size Structure of Barbus petenyi (Actinopterygii: Cypriniformes: Cyprinidae), the River Iskar, Bulgaria), Acta Zoologica Bulgarica (Supl.4), 201-210

15. Uzunova, E., D. Kisliakov (2014), Fischdurchgängigkeit der Wasserdruckmaschine), Korrespondenz Wasserwirtschaft, DWA auf der IFAT, 7. Jahrgang, Nr.2

16. Vowles, S., S.P. Karlsson, E. P. Uzunova, P. S. Kemp (2014), The importance of behavior in predicting the impact of a novel small-scale hydropower device on the survival of downstream moving fish, Ecological Engineering 69, 151-159 